\title{
The Queen of the Sciences: Reclaiming the Rightful Place of Theology and Creation
}

\author{
Dr. Abner Chou \\ PhD, Old Testament, The Master's Seminary \\ John F. MacArthur Endowed Fellow and Interim President at The Master's University
}

\begin{abstract}
Historically, theology was viewed as the queen of the sciences. But in recent days this has fallen out of favor, especially due to the unpopularity of the doctrine of creation. Instead, science is viewed as its own autonomous foundation. This article surveys through the issues surrounding creation and argues that a realism of biblical authority and revelation establishes theology and creation as a necessary framework for science. It also will contend that the interpretation of Genesis $1-3$ is clear and clearly historical as well as that the doctrine of creation is inextricably linked with the totality of Christian theology. Even more, it will survey God's plan of redemption and illustrate that creation is the basis and driver of God's redemptive work. Creation holds the answers to the toughest questions people have about this world and evil. With that, by virtue of divine authority, theology is the queen of the sciences, and within this, the doctrine of creation helps to restore the true value and beauty of science. Therefore, it should be the starting point of the sciences.
\end{abstract}

It is fitting to begin this inaugural issue with a discussion on creation. As Scripture states, creation is "in the beginning" (Gen 1:1). Accordingly, creation begins the entire biblical storyline. It sets the plot and trajectory of God's entire plan. It undergirds the progression of scriptural revelation and theology. And because it is so foundational, it also formulates one's worldview. Consequently, the opening chapters of Genesis set one's perception of the sciences. That is not only because creation constructs the very structure of one's worldview but also because it has direct bearing upon science itself. The opening chapters of Genesis account for the very origin of the material and phenomena that the sciences observe. For these reasons, theology classically has been known as the "queen of the sciences." It is the overarching standard of truth and the very framework in which all the sciences are based upon, operate, and 
abide.

However, questions and challenges have arisen concerning this passage of Scripture. The theory of evolution has provided an account of origins apart from any notion of Creator or creation. Evolutionists have pointed to numerous observations in support for their assertions [Mey17]. Due to the persuasiveness of these arguments, Christians have considered and even adopted aspects of evolution to varying degrees. On one end of the spectrum, there are some who entirely reject evolutionary accounts of origins and argue for young earth creationism. There are also others on the opposite end who argue for theistic evolution, which contends that God used evolutionary processes to formulate this world [Mey17, pp. 40-43]. And there are people in between these two extremes. Because of such significant controversy, some wonder if creation matters. It seems to be a contentious and unclear issue. Good people disagree. So some may believe that perhaps the Bible does not provide enough information to reach a definitive conclusion, and one should not have a dogmatic view on this. Moreover, people often perceive creation as something which took place so long ago that it has little pertinence upon the present time and upon more weighty doctrines in the Christian faith. For these reasons and more, the temptation is to isolate these passages in Genesis to something that is ambiguous and should not factor heavily in how we understand the world and science. To some, Genesis 1-2 can simply be relegated to a text that can have multiple interpretations. At that point, creation has become a pawn.

The goal of this article is to reclaim theology as the queen of the sciences and creation as a key starting point. This article will survey through the doctrine in its scriptural presuppositions, substance, theological stakes, and significance. In doing so, a growing case emerges that the doctrine of creation is not negotiable, secondary, isolated, irrelevant, or a liability. Rather, it carries divine authority and clarity, acts as a cohesive force in Christian theology, and even provides some of the most compelling answers to the most profound questions of life. Creation is not a doctrine to be isolated or set aside; it should not be an afterthought in the pursuit of science. Rather, the truth of creation, by virtue of its character, should be put on center stage. For it not only wields the definitive authority to determine our understanding of the sciences, but also the beauty to show the nobility of the sciences. Creation then is truly part of the queen of the sciences.

\section{Scriptural Presuppositions of Creation}

The entire discussion of creation and the centrality of theology must begin with bibliology. After all, the question of the queen of the sciences all depends upon how one perceives reason versus revelation. In recent history, the advent of modernism has entrenched a skewed view of the nature of Scripture and human understanding in popular thinking. This is all in the name of objectivity [Moro3]. Ironically, what is needed is to recover true objectivity about 
the nature of revelation and the limits of human knowledge. Only then can one understand why theology is the queen of the sciences. Such a framework is philosophically necessary as revelation can alone provide the basis for and the authentication of what science depends upon and assumes. In that way, bibliology is the cornerstone to the response of how creation and theology relate with the sciences.

A helpful way to discuss this is to define and think through three categories: special revelation, general revelation, and knowledge. Within each category, we can survey though the source of each type of information, what it covers, how it covers it, and what it accomplishes. Doing so will allow one to put revelation and reason in their proper places.

\section{Special Revelation}

With this in mind, the first category to cover is special revelation. The source of special revelation is God Himself, for in it He directly reveals His truth (cf. Deut 29:29; Eph 3:5-9). This can happen through a variety of means including directs acts of communication, dreams and visions, and the incarnation of Christ who explained the Father (cf. Jhn 1:18) [MM17, p. 74]. Special revelation also occurs in Scripture. In fact, Scripture is the foremost means of such revelation for it is the repository of the revelatory acts God desired His people to know (2 Tim 3:16b) [Rey98, pp. 116-26]. This is the point of verbal plenary inspiration. This doctrine articulates that while men were involved in the writing of Scripture, their fallibility never contaminated any aspect of Scripture. Rather, God superintended by His Spirit that every word-all Scripture-is His own as men spoke from Him (Exod 4:12, 15; 2 Tim 3:16; 2 Pet 1:21) [Rey98, pp. 25-44]. Inspiration declares that Scripture is not in any way from man but totally from God. It is pure special revelation.

The primacy of Scripture as special revelation is seen in that God Himself traces the work of special revelation in terms of the giving of Scripture. Hebrews 1:1-2 notes, "God, having spoken long ago to the fathers in the prophets in many portions and in many ways, in these last days spoke to us in His Son." These verses provide the breadth of God's work of special revelation. The descriptions of "long ago" and "in the last days" exhibit God's revelatory activity throughout all history [Bru64, Ell93, Lan91]. The verses also mention God's "prophets" who convey God's direct message, "many ways" which include visions and dreams, and God working in "His Son" which deals with Christ's ministry. As noted, special revelation includes all of these means. Nevertheless, they all take place "in many portions" of inspired writ and revolve around God "speaking," which refers to that which He verbally communicated. Scripture is at the core of special revelation. In fact, this entire framework about all of God's activity of special revelation is given by Scripture itself-in this case, it is given in the book of Hebrews. Accordingly, epistemically speaking, one only knows of the nature of special revelation by what is revealed in Scripture. This illustrates that the ultimate foundation for 
grasping special revelation is found in God's Word. With that, God is the source of special revelation and Scripture is the foremost giving of that special revelation.

What God reveals in Scripture is staggering. This includes the theological depths of the various attributes of God in their loftiness (Isa 6:1-3; Ezek 1:1-2:1), transcendence (Isa 40-48; Job 26; Pss 96-99), and compassion (Exod 34:6-8; Ps 103). Such revelation also involves the nature of $\sin$ (Ps 14; Rom 1-3) and salvation (Isa 52:13-53:12; Rom 3:21-26), morality based upon His holiness (Lev 19:1), the work of the Spirit (Ezek 36:26-28), and the preeminence and glory of His Son (Rev 4-5). However, God does not merely reveal theological information in Scripture. Rather, the claims of Scripture also entail matters of history (1 Kgs 15:7) and observations about the phenomena of this world (Job 36:27-33). Indeed, these claims are a crucial part of the theological assertions of Scripture. God's theological assertion about His plan for the world necessarily entails historical facts from beginning to end (Gen 1:1; Rev 22:1-9). Similarly, God's theological assertion about the nature of man is predicated upon his origins. Thus, as will be shown, if the historical claims of Scripture fail, its theology collapses as well [Cho14, pp. 24-33]. ${ }^{1}$ We cannot have one without the other. This is where the doctrine of inerrancy enters in. That doctrine reminds us how Scripture has no error in any of its assertions in the original manuscripts; all that it declares in every aspect of that declaration is true (cf. Jhn 17:17) [Beao6, Cho16]. Consistently, special revelation makes authoritative claims about reality that cannot be limited to just spiritual ideas but include a plethora of details of what takes place in this world. Even more, Scripture reminds us that its details are not merely without error but also disclose the full truth about these facts. Man may observe something but not know the purpose behind it (cf. Ecc 3:11). But revelation explains the data the way God wholly intended it to be (cf. Deut 29:29). Furthermore, Scripture contends that its information has far greater certainty than human experience. In Peter's final epistle, he recounts how he was an eyewitness to Christ's glory (2 Pet 1:16-18). However, although his experience was so compelling, the apostle proclaims, "And we have as more sure the prophetic word" (2 Pet 1:19). Peter declares that Scripture is even more sure than his experience of God's revelatory activity. Scripture provides greater certainty than one's own senses, memory, or observation. Consequently, special revelation covers a diverse set of information with a purity, depth, and certainty that goes beyond human derivation.

Scripture is also effective. As Psalm 19 says, God's Word converts the soul, makes wise the simple, enlightens the eyes, and stands forever (Ps 19:7-9f). The Spirit uses His Word to transform God's people. Second Timothy 3:16 not only affirms Scripture's inspiration in that it is God-breathed, but also that it is "profitable for teaching, for reproof, for correction, for training in righteousness." Scripture, under inspiration, contains the revelation of God that people for all time need to hear, communicated in perfection, and empowered to be effective

\footnotetext{
${ }^{1}$ See also later discussion.
} 
among the saints. With that, special revelation, and in particular Scripture, occupies a unique place in thinking about information. It covers a great breadth of data from theology to history, from the supernatural to the natural order, for it makes claims on all of this. It also has great depth, for it reveals with absolute certainty and truthfulness the full truth about life and the world categorically and in their details. Its information is also not inert. It has the power to save and change lives forever. Already, one might be able to observe why theology is the queen of the sciences. With such range and authority, it covers every discipline. And when something is done in accordance with God's Word, it elevates the dignity of that activity.

\section{General Revelation}

That being said, there is a second category to be discussed, and that is the category of general revelation. Since this is a form of revelation, the source of this is from God. As Romans 1 describes, God Himself has made this revelation evident (Rom 1:19). Consistently, general revelation declares absolute, inerrant, and authoritative truth about God, truth that man could not otherwise determine. However, unlike special revelation, the means of this revelation is different. As opposed to being in Scripture, general revelation is often associated with creation. For example, Psalm 19 describes how the heavens proclaim the glory of God and how nothing is hidden from the heat of the sun in the sky (Ps 19:1-6). Likewise, in Romans 1, it talks about how God's power and divinity are known through what has been made (Rom 1:20). However, there is a significant qualification about the means of creation as general revelation; namely, it is found in creation categorically as opposed to in individual details. Psalm 19 emphasizes the existence of the sky and the sun as a whole as opposed to a particular property of these entities. It stresses how all people are exposed to those elements. Similarly, Romans does not speak of individual components of creation but rather creation in its collectiveness-that

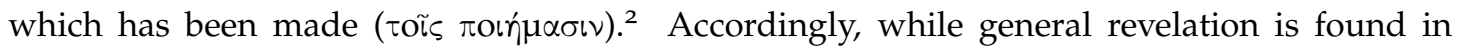
creation, it refers to creation in totality and not in its detail, as a whole and not in part. Such universality is not incidental to the category of general revelation. After all, a major purpose of general revelation is to make all without excuse, and that can only occur if general revelation is found systemically in all creation. If the means of revelation was located in a specific feature of creation or within man's particular observation, not everyone may have access to that information or could figure that idea out. Because of this lack of access, man would then have an excuse before God. However, the entire point of general revelation is to show that all are aware and condemned. That requires the means of such revelation be found throughout creation. As the name general revelation suggests, the very means of conveying this revelation

\footnotetext{
${ }^{2}$ Most likely, akin to the rest of the plurals in the verse, this is a form of collective plural [Walg6]. Paul also implies that conscience falls into general revelation. In Romans 2:14, he speaks of how conscience condemns people, proving that they are a law unto themselves [Gato2].
} 
is general.

That is not the only way general revelation is general. It is also general in its content. Both Psalm 19 and Romans 1 make clear that general revelation pertains to the existence of God and His power. Psalm 19 speaks of the "glory of God" (Ps 19:1) and Romans speaks of God's eternal power and divine nature. The latter does not refer to God's various attributes but the

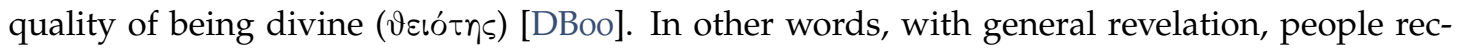
ognize that the concept of God is true but do not necessarily know who this God distinctively is. While this information is enough to condemn, making all men without excuse (cf. Rom 1:20), it is severely restricted. It only expresses a singular truth about God's existence and not anything about other categories of theology, God's biblical theological plan, and certainly not about His work at the beginning of that plan; namely, creation. General revelation is very general in that it covers a very limited set of truths in a very limited way.

Consistently, general revelation is general in its effect. As mentioned, it does not have the ability to save but only condemn. In addition, it can be inhibited. Paul begins an entire discussion of general revelation with the reality that men "suppress the truth in unrighteousness" (Rom 1:18). With that, general revelation, unlike special revelation, is truly general and thereby quite restricted in its means, content, and effect.

\section{Knowledge}

One third and final category remains: knowledge. The Scripture often discusses the area of human understanding (cf. Job 28:1-11; Prov 3:5-6; 1 Cor 1:18-31; Col 2:8; 1 Tim 6:20). Unlike divine revelation, the source of knowledge is man himself. To be sure, any true knowledge ultimately comes from God who established it in this world (Prov 8:22-31), but unlike revelation where God is directly revealing (cf. Rom 1:19), knowledge comes as man discovers and discerns. In that way, there is a categorical difference between revelation (whether special or general) and knowledge, and such a distinction results in other marked differences between the two. Unlike revelation, Scripture describes how knowledge can take truth and pervert it (Rom 1:21-23, 28). It is unsure as it assumes something but only under cross-examination discovers something different (Prov 18:17). It is erroneous as it discerns a certain path which leads to death (Prov 16:25). It can be futile as one only learns things that are incomplete and partial. That is why Ecclesiastes says, "Because in much wisdom there is much vexation, and whoever increases knowledge increases pain" (Ecc 1:18). Solomon states this in context because in learning facts, one cannot see all that God intended by them so one learns of problems without solutions, insights without balance, criticism without hope, and ideas without purpose [Enn11]. Those deficiencies of human knowledge lead to vexation [Lan92]. Human knowledge can not only be erroneous and limited but fallible. Knowledge may give one a sense of confidence, but Scripture observes how spiritually blind people grope in the dark 
to find truth but cannot (cf. Acts 17:27; Job 12:25). While human knowledge can span the breadth and depth of creation, its understanding of these things is far from the certainty and completeness of revelation. That is not only because finite people are involved but even more so given man's depravity (cf. Eph 4:17-19) and how they have an unfit mind (cf. Rom 1:28). Thus, any fact or aspect of truth that one can observe is often obscured by sinfulness.

HAVING DEFINED THESE three categories, one can see that man's temptation is to confuse them. At times, people observe that general revelation is tied with creation and assume that whatever they observe from creation then must be general revelation. Such an assumption gives rise to the adage "all truth is God's truth" [Jono3]. However, that is incorrect. As noted, the mechanism of general revelation is not the individual components within creation but the very whole of creation itself. Moreover, its revelation is not discerned by man's observation but by God's revelatory activity, as He unveils it to each man (Rom 1:19). It is not man discovering things about God but God using the totality of creation to declare truth to man. Furthermore, the truth that is declared is not all the insights people think they might have from creation. Rather, it primarily concerns the truth of the existence of God. Thus, the notion that man can gain theological understanding solely by reasoning through aspects of creation is not what general revelation is nor how it works. What people have at this point is their knowledge and not revelation, and it is a category mistake to elevate their fallible reason over inerrant revelation. Similarly, people may also identify God's character displayed in various details of creation, assume that these details themselves revealed such truth, and therefore that their discipline is engaged in revelation. However, that is not exactly what is taking place. Theologically speaking, when people observe the character of God manifest in His created order, the created order is not the source of that information. Scripture is where that revelation takes place. That is where people have learned with certainty about who God is. They then apply what they have learned to their discipline. This is an important reminder that knowledge is not inherently evil. It can and should be used for God's glory; that is how God designed it to be (cf. Pss 8:3; 66:3; 92:5; 111:2; 104:24). That being the case, the created order becomes the illustration of special revelation but is not special revelation itself.

Man's temptation is to elevate knowledge to the level of revelation, but they are not on the same level at all. They do not have the same source and thereby do not have the same certainty, value, content, completeness, power, or authority. That alone demonstrates that knowledge can never have the same influence as revelation. Furthermore, the very nature of knowledge shows a critical necessity and dependence upon revelation. For instance, science itself has certain assumptions including the reliability of one's senses, the existence of an independently verifiable reality, and the presence of truth that can be discerned and articulated [Moro3]. However, postmodern thought has demonstrated significant philosophical challenges to those presuppositions [Moro3, Mori7]. How can one know that what he has seen or experienced 
is true? Even if someone validates that experience, how can one even know that the person had the same experience, conveyed true affirmation, and even exists (as opposed to being a figment of one's imagination)? These epistemological problems are significant. However, if such things cannot be definitively proven, then science-which relies upon observation, the existence of a universal reality, and the verification of repeatability-cannot work [Mor17]. This illustrates that man's reasoning cannot autonomously deduce a self-sufficient system of thought. In actuality, the more they think, the more they realize, as wisdom literature long ago observed, that there are sizeable gaps in man's assumptions and that this too is futility (Ecc 1:18; Job 9:1-2; 12:1-12; 20:1-16)3. For science to work, much must be assumed which cannot be definitively proven by human reasoning. Revelation is not just a crutch for the weak; it is a philosophically necessary crutch for science as well.

The book of Job illustrates the very limitations of human knowledge and the necessity of revelation. In fact, it is more than illustrative. As the chronologically first book of Scripture, its function is to introduce Scripture and, within this, to demonstrate why one needs a Bible to begin with [Wal12, Lon12]. That is why the book spends a considerable amount of length discussing wisdom. While suffering is found at the beginning of the book and drives the plotline, the vast majority of its chapters is consumed with dealing with the debate between Job and his friends. They endeavor to figure out why Job suffered. And they pull on the breadth of human knowledge to answer this question. They draw on history (Job 5:27), philosophy (Job 11:1-7), and frequently observations from nature (Job 8:11-18; 25:1-6). However, none of Job's friends ever come close to the right answer. None of them ever articulates anything close to what took place in Job 1-2. In actuality, most of their conclusions blatantly contradict the truths stated therein (Job 8:20; cf. Job 1:1). Furthermore, what they do say, even if legitimate in certain circumstances, only leads Job to further despair. Therein is the nature of human knowledge. It can be brilliant. Some of what Job's friends say are sublime descriptions of God and this world (cf. Job 11:1-20), even affirmed later by New Testament writers (1 Cor 3:19; cf. Job 5:13). Nevertheless, these facts lack completeness and so provide no comfort to Job. All of this leads Job to conclude that man is lost, groping in the dark (cf. Job 12:25). Human knowledge is not the panacea that one might think it is. Human observation can actually draw a completely wrong conclusion and make things worse rather than better. Having said this, one cannot fault Job's friends too harshly. How could they know what truly and completely

\footnotetext{
${ }^{3}$ For example, in Job 9, Job responds to Bildad's scientific explanations with "In truth, I know this is so." Man does make correct observations about this world and its operations. But it cannot solve the question "But how can a man be right before God?" Science cannot see everything. This is also brought out later on in Job 38 where God answers Job with a challenge of where he was when God laid the foundations of the earth or if he ever commanded the morning. Such statements remind Job of his inherent limitations in making observations and deducing God's character from this world. Job simply has not seen enough of the entire picture to make such a judgment call. See also [Enn11]: "The reason why even his royal wisdom quest is futile is that the more you know, the worse off you are. It is futile not because of what he cannot find out, but because of what he does find out. As he puts it, wisdom is accompanied by sorrow, knowledge by pain."
} 
took place? That involves heaven itself (Job 1:6) and thus only heaven could reveal it. And that is precisely why revelation is needed. Human knowledge cannot know things with certainty or completeness. Therefore, heaven must disclose it.

Toward the end of the dialogues, Job reflects upon all of this. In Job 28 he begins by acknowledging that man has tremendous talent and intelligence. His advancements in mining illustrate this (Job 28:1-11). Nevertheless, he questions where wisdom is truly found and concludes that man has no ability in and of himself to perceive (Job 28:12-14), acquire (Job 28:15-19), or invent wisdom (Job 28:20-22) [Har88, Ald93, Wili5]. The reasons are simple. Man, being part of the world, cannot stand outside of the world and objectively observe the complete picture of what is taking place (Job 28:12-13). Man also does not have the power to control the world and thereby his knowledge does not wield such effectiveness. He only has money, which is a poor substitute for true might and wisdom (Job 28:15-19). In addition, man does not have the skills to discern wisdom, for it requires the ability to know all things natural and supernatural (Job 28:20-22). Job acknowledges that man's knowledge can be astounding, but he does not have complete wisdom. And in context, this is Job's realization of why he and his friends cannot figure out his problems. Instead, Job realizes that the solution is found elsewhere. As he says in the final verse of Job 28, "So He said to man, 'Behold, the fear of the Lord, that is wisdom; and to turn away from evil is understanding." Why is fear of the Lord the beginning of wisdom? God alone is the one who sits outside creation and sees all things (Job 28:24). God alone is the one who controls creation and has the knowledge that has true power (Job 28:25-26). God alone is the one who knows all things natural and supernatural and has discerned all things (Job 28:27). Therefore, there is one who knows what He is talking about, and there is man whose knowledge is shallow, incomplete, and errant. When one fears God, he listens and surrenders to Him. And in that moment, man finally becomes wise because he heeds the only one who knows what He is talking about. The book of Job is a lesson on the strict limits of man's understanding and that if one is to have any real wisdom or answers, one must fear and surrender to God. Without this, one will appear smart like Job's friends but will also be just as foolish and unhelpful as they were. Man needs revelation to figure out life.

As STATED ABOVE, out of any line of argumentation, bibliology is what most definitively locks in theology as queen of the sciences. That is because it demonstrates the distinction between reason and revelation. It shows how revelation is more certain and complete than reason, how revelation undergirds all of reason, and how reason then can never trump revelation. As Job has observed, man on his own cannot come up with the answers, God must supply them, and thus the posture of man cannot be one of intellectual self-reliance but of the fear of God. With that, theology acts as the starting point for the sciences, not only relative to authority and sureness but even in philosophically accounting for the assumptions of the discipline. For 
in Scripture are the reasons why we know that reality, truth, the reliability of our senses, and even communication all exist. Philosophers have a point. We may not be able to justify these things on our own, but we do not have to. God has revealed it so, and the grounding for that is in creation - the way God made this reality, established it in wisdom and truth (Prov 8:22-31), and made man able to understand and communicate (Exod 4:11). With that, theology and even creation itself are queen of the sciences.

\section{The Substance of the Doctrine of Creation}

At this point, one might acknowledge that theology occupies an authoritative place over science. However, an issue arises of whether we can really know what Genesis 1-3 says. How can we be sure that Genesis 1-3 reads as complete history of what took place at the beginning of the world as opposed to having some flexibilities that can incorporate what people have observed in evolution? If creation cannot be confidently defined, then its place as the queen of the sciences is simply a theoretical point. An undefinable definition cannot define anything.

Hence, the question is: What does Scripture say? Is there a way to discern the Bible's claim about the nature of the opening chapters of Genesis? I have commented on this in other publications and will summarize the line of argumentation here [Cho14, pp. 19-46]. Essentially, three major hermeneutical options exist for thinking through the claims of Genesis. First, one could argue that parts of the Genesis account are not actually claiming to be historical, which allows for a certain level of accommodation to evolutionary claims. Second, one could argue that the whole of the Genesis account is not claiming to be historical which would then provide no obstacle in affirming an evolutionary perspective to whatever degree one desires. Third, Genesis may be claiming to be historical both in part and whole. If the latter is the case, Scripture is incompatible with an evolutionary conceptualization of origins. In essence, discerning this issue is a process of elimination. By disproving the first two options, we establish the third.

\section{Evaluating Whether Particular Claims are Historical}

With this in mind, one can broach the first hermeneutical possibility. Does Genesis 1-3 contain certain details that do not claim to be historical? Examples of such thinking would include gap theory, day age theory, Genesis $1-2$ as poetic genre, phenomenological language, and the need for harmonization. ${ }^{4}$ While each of these ideas comes at the subject from a unique angle, the end result is the same. They contend that certain descriptions in Genesis are ambiguous

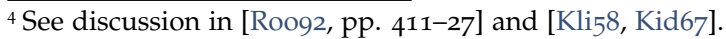


and not meant to be read strictly as history. There is flexibility in the text that does not put it in conflict with what man has observed.

However, these theories do not stand scrutiny. For example, gap theory argues that a disjunctive clause with the perfect tense of the verb "to be" in Hebrew implies that Genesis 1:1-2 is not necessarily contiguous and may even imply that there was a deconstruction of original creation as the earth became empty and void. However, an investigation of both the disjunctive clause as well as how the perfect verb היה operates does not support such conclusions [Roog2, pp. 316-23, 411-27]. In fact, even a standard Hebrew grammar defines disjunctive clauses as often operating as circumstantial clauses delineating the very situation of the main clause [WO9o]. The syntax of the text is not ambiguous or suggestive of what gap theory alleges at all. It is clear in its presentation.

Likewise, a day is also defined in Genesis 1. In Genesis 1:5, Moses actually uses a cardinal number (אֶ, one) as opposed to an ordinal number (ראוֹ, first). All the rest of the days are numbered by ordinal numbers, so the initial exception is significant. In saying, "And there was evening and there was morning, one day" (Gen 1:5), the narrative does not merely talk about the first day but defines what constitutes a single day [Steo2]. It is evening and morning. The text itself defines its own terms contrary to day age theory.

Similarly, assertions that the opening chapters of Genesis are poetic are also linguistically tenuous. A major marker of historical narrative is the presence of the wayyiqtol verb form [Boyo8, pp. 163-92]. Genesis 1-3 statistically has this verb form in the exact ratio expected for narrative and not poetry [Boyo8, pp. 163-70]. To argue that Genesis is poetry and thus has a more literary flexibility in interpretation is baseless. In fact, such an argument is additionally flawed in that poetry can convey historical facts (cf. Pss 78; 105-6). Genre does not determine the content of a text but rather sets the presentation of those claims and the desired response [Thoo2].

Another suggestion has been that since Genesis (or really Scripture as a whole) contains phenomenological language or language of appearance, it must not be historical [Lam13, p. 50]. To be sure, stories throughout Scripture record things from certain people's perspective. A famous example is how Scripture records how the sun rises and sets (Gen 19:23). However, such claims do not undermine the accuracy or historicity of a text. For one, the text claims that phenomenological language is what one observes from his perspective. Such an assertion is true and accurate. Furthermore, for such an observation to occur, it presumes one saw something which places the experience in the realm of time and space. Thus, even though an event may be redescribed from an external perspective, such a truth does not negate that an event exists or demand a parabolic interpretation.

Finally, some argue that potential conflicts between Genesis 1 and 2 argue against a strict historical reading of the text. For example, Genesis 1:11-12 says that vegetation sprouted, but Genesis 2:5 says that plants had not yet grown. Another supposed conflict occurs when Gen- 
esis 2 talks about how God formed Adam (Gen 2:7) and then formed every beast of the field and bird of the sky (Gen 2:19). However, Genesis 1:20-24 states that the creation of animals occurred before Adam was created. Because of these alleged contradictions, some argue that Genesis 1 and 2 cannot be read as precise historical narratives since the accounts do not agree on what happened. Instead, they contend that a more generic reading is preferred which then allows for Genesis 1 and 2 to harmonize with each other as well as with current scientific thinking [Walı3, Fut98]. However, the supposed inconsistencies can easily be reconciled. The plants mentioned in Genesis 1:11-12 are not the same terms or types as mentioned in Genesis 2:5. Trees and grass, which are not cultivated by human beings, were created fully grown as Genesis 1 explains. But cultivatable plants, like shrubs or plants of the field, were created in their seed form awaiting man to nurture them as Genesis 2 states. It is not a contradiction at all if different plants were created in different ways as Genesis 1-2 describes. The alleged conflict concerning the ordering of the creation of animals and man can be solved similarly. The animals described in Genesis 1 are also not the same terms or types of those found in Genesis 2.5 Furthermore, for this particular issue, another point of explanation is to understand that the verb form in Genesis 2:19 does not always have to deal with strict chronological sequence, especially when the clause provides the explanation of the circumstance surrounding a situation (Num 1:47-49; Ruth 2:3; 2 Sam 14:5; 1 Kgs 13:12). That is precisely the case here [Ham9o, p. 176],[Mat96, p. 214]. The text may very well be saying that God had already formed these animals to bring to Adam to name. This understanding is reflected in quite a few modern translations. In light of this grammatical reading, both Genesis 1 and 2 provide the same order after all. ${ }^{6}$ The supposed conflicts between texts are hardly insurmountable.

Does Genesis 1-2 have certain details that are ambiguous or interpretatively flexible? The above analysis has demonstrated that this is not the case. In fact, it demonstrates the opposite. Genesis 1-2 not only have clear grammar and defined terminology, they even employ very technical terminology, as the designation of plants and animals in these chapters demonstrates.

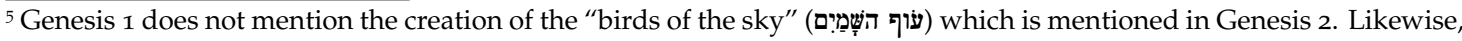

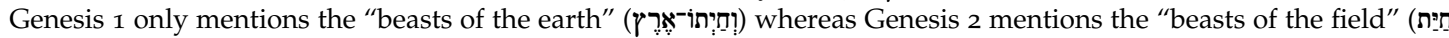

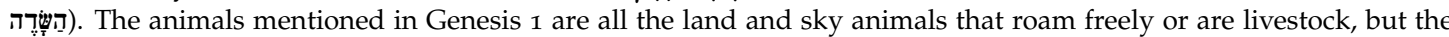
ones in Genesis 2 are land animals that are used to cultivate the land and birds that man has dominion over. In fact, God even mentions in chapter 1 that the "birds of the sky" are those birds which man has dominion over (cf. Gen 1:26).

${ }^{6}$ To be clear, both factors of the distinction between animals named in Genesis 1 and 2, and the fact that Genesis 2:19 must be reflecting on what God had already done before Adam's creation are not mutually exclusive. It could very well be that God formed these unique sets of animals before He made man and then later brought specific animals to him to name. That best accounts for all the evidence presented thus far [Ham9o, p. 176],[Cas61]. The two supposed sets of discrepancies given above actually share a parallel. All plant life was created on the day given in Genesis 1 but different plants were created in different ways to serve different functions expressed in Genesis 2. In the same way, a pluperfect reading of the verb and acknowledgement of the technical designation of animals also recognizes that all animal life was created on the respective days given in Genesis 1 but with different classifications and emphases to be utilized for a purpose in Genesis 2.
} 
All of this argues that Genesis 1-2 is a carefully thought out and crafted narrative, one with attention to detail. Such exacting precision in the narrative argues against the notion that there is hermeneutical flexibility within it.

\section{Evaluating Whether the General Tenor of Genesis 1-2 is Historical}

In the history of interpretation, theories like gap or day age have been abandoned by scholars in favor of alternative approaches that argue that Genesis 1-2 is designed more like ancient near eastern (ANE) myth [Walog]. This shifts the discussion from discerning whether particular claims of Genesis are historical to whether the entire account intends to be historical. If Genesis 1-2 corresponds more to the myth of Israel's contemporaries, perhaps the text is more like a parable, intending spiritual truth but not necessarily telling a historical story.

The support for this suggestion comes from the extensive overlap between Genesis and ANE myths. Some of the most dominant comparison are as follows:

- The Hebrew word "deep" in Genesis 1:2 sounds like the word for the goddess Tiamat of the Ancient Near Eastern creation myths.

- Both have waters above and beneath separated by a firmament.

- Both have light before the sun, moon, and stars.

- Both describe mankind's failure to please a deity.

- Both refer to plants that confer immortality.

- Both mention a serpent.

- Both describe a global flood [Cho14, p. 34],[Lam92, p. 527],[Gro85],[HYoo, p. 451].

At first glance, these seem quite compelling. However, two points should be raised. First, on a deductive and theological level, Scripture maintains itself as the truth and does not accommodate falsehood. Paul repeatedly repudiates myths (1 Tim 1:4) and exhorts any leader in the church to do the same (1 Tim 4:7; Tit 1:14). Heeding myths is the sign of a false teacher (2 Tim 4:4). One may object that the myths Paul talked about were not the stories of the ancient near east; nevertheless, the rhetoric points out that Paul's objection against the false teachers is that they taught things that were a tale or legend, that which was not true but fictional. While targeting a specific issue, he deals with the entire category [Beao6, pp. 30133]. Consistently, Peter asserts that in presenting the life of Christ, they did not follow myths but were eyewitnesses (2 Pet 1:16). The contrast between myths and an eyewitness account is one of fiction versus fact, fantasy versus verifiable history [Bau83],[Scho3, p. 313]. The notion of affirming incorporation of legendary material into Scripture is problematic from the claims of the biblical writers who composed it. 
Second, inductive analysis supports what the biblical writers assert. In comparing ANE myths with the Genesis account, the similarities are not as similar as one might perceive. The list above is compelling, but the list above is the result of an interpretative process. For instance, scholars have observed that both Genesis and ANE myths have waters above and beneath separated by a firmament. While Genesis states this directly (cf. Gen 1:7), ANE myths speak of how one deity split a goddess in half and put half her body above the sky and the other half below it [Lam92, pp. 135-40]. Such a description is far from what Genesis articulates. Genesis talks about physical matter; the ANE myths speak of deity. Genesis talks about God's creation; ANE myths speak of battle. Genesis speaks of a singular God making; ANE myths speak of a pantheon in conflict. In essence, as scholars note, Genesis is different than ANE myths in that Genesis demythologizes these stories [Wat27]. In using such a term, these scholars acknowledge that Genesis is far from myth. Consequently, there are substantial differences between Genesis and myths. On top of what has been just mentioned, Genesis does not use sexual imagery to discuss creation [HYoo, p. 6]. As mentioned, it does not use poetry which is a main vehicle for ANE myths. It also does not use terms of evolutionary development, which ironically are present in certain myths of the time. For example, Egypt has the term "evolve" which lexically seems to denote such a process because it is used to describe how a chicken develops from an egg.7 Furthermore, Genesis uses temporal markers to discuss a distinct cosmology as opposed to ANE myths which are more cyclical in nature and describe the seasons [Gro85]. Put differently, Moses deliberately avoids the terminology, genre, temporal markers, descriptions, and religion associated with ANE myths. While modern scholars may be drawn to make comparisons, those in the ancient times would have seen these stark distinctions and understood that Genesis was anything but ANE myth. Therefore, the idea that the biblical creation account posits itself like a parable or fictional story is not sustained both by the nature of Scripture in totality as well as by the specific assertions in Genesis 1-3. Genesis presents itself as history as opposed to ANE myth.

\section{Evaluating Whether Genesis Claims to be Completely Historical}

By process of elimination, if Genesis does not make ahistorical claims in individual details or general tenor, then it is historical in both part and whole. It is completely historical. Two lines of evidence support that Genesis 1-3 asserts itself as history. Fundamentally, the mentality of Scripture as a whole ties theology with the reality of history. A simple proof of this is found in Paul's logic concerning the resurrection. In 1 Corinthians 15 , the apostle does not say that our Lord's historical resurrection is irrelevant as long as the theology of the resurrection can be sustained. Instead, he contends that if Christ did not rise from the dead, then the theology

7 See [Cho14, p. 36, fn. 40]. 
of the resurrection in its hope and power is non-existent (cf. I Cor 15:1-19). Theological truth is tied with history. However, the rationale that history and theology are tied together extends beyond the resurrection. For example, Romans 5:8 ties the historical reality of Christ's death to the demonstration of God's love. Similarly, Peter ties the global flood to the reality that God will judge the earth once again (2 Pet 3:4-6) [Scho3, p. 374]. In addition, Hebrews 11 ties the historicity of Old Testament events to the efficacy of faith. In that specific passage, if the events listed did not happen, how can one argue that faith is effective when it never really had an effect? Interestingly enough, Hebrews 11 includes creation in the list of history it recounts (cf. Heb 11:3). The resurrection is not the only event where its historicity is mandated for theological reality. The logic found in 1 Corinthians 15 is truly found throughout the argumentation of Scripture. Accordingly, one expects this pattern when reading Genesis, especially since, as argued above, it makes no claim to the contrary.

In addition, the way Genesis presents itself is the way Scripture reads every part of it. Moses himself constructs subsequent narratives in the Pentateuch to uphold a historical reading of Genesis 1-3. Even in Genesis 4, Adam is treated as a real human individual who has relations with his wife and has children (Gen 4:1). In the giving of the Ten Commandments, Moses records how God Himself declares, "For in six days Yahweh made the heavens and the earth, the sea and all that is in them, and rested on the seventh day; therefore Yahweh blessed the sabbath day and made it holy" (Exod 20:11). The directness of this quote is significant. The Lord could have used comparisons, analogies, or even language of similarity all of which are found in the Pentateuch about other matters (cf. Gen 3:5; 13:10; Exod 15:11; 24:17). However, that is not the case. The quote above makes an emphatic claim, without any qualification, about how God made the world in six days and rested on the seventh. With that, the Pentateuch affirms the historicity of the creation account. Other books follow suit. First Chronicles begins with the genealogy of Israel with Adam, again presuming his existence (1 Chron 1:1). Psalm 104, in poetry no less, recounts God's wisdom in how He created the world, and the poem is structured around the order of creation provided in Genesis 1 [Kid]. Amos 4:13 speaks of God making the mountains and, in the next chapter, the stars (Amos 5:8). In addition to all of this, the Lord Himself affirms the reality of the Genesis account. Matthew 19 says, "And He answered and said, 'Have you not read that He who created them from the beginning MADE THEM MALE AND FEMALE, and said, "For THIS REASON A MAN SHALl LEAVE HiS FATHER AND MOTHER AND BE JOINED TO HIS WIFE, AND THE TWO SHALL BECOME ONE FLESH"?"' Jesus specifically affirms that God is the one "who created" Adam and his wife. This is a special creation of man as Genesis describes. Paul affirms the existence of Adam in paralleling Adam and Christ (Rom 5:12; 1 Cor 15:45). Luke does so as well in his genealogy (cf. Luke 3:38). Both Peter and the author of Hebrews not only affirm that God created the world but specific details within Genesis, including that He formed the earth from the water (2 Pet 3:5; cf. Gen 1:2, 7, 9) and that He created by His Word (Heb 1:2; cf. Gen 1:3). Paul likewise affirms 
that God created light (2 Cor 4:6). This list is far from comprehensive, and one could also cite examples of how the historicity of the creation account in its details is affirmed by Daniel, Ezekiel, Isaiah, and other New Testament writers. ${ }^{8}$ Suffice it to say that no other reading of Genesis is presented in Scripture. Thus, to posit an alternative interpretation of Genesis is not merely contained to the passage but will have a ripple effect to a whole host of other passages as well. This is not an isolated interpretation.

Therefore, Genesis 1-3 does not have hermeneutical ambiguity. Its details are not ambiguous since its terms (like day and the grammar of Genesis 1:1-3) are clearly defined. Its tenor is not ambiguous as Moses goes out of his way to differentiate his writings from ANE myths. All of this sets up for Genesis clearly asserting itself as history, an assertion affirmed without reservation by the rest of Scripture. The way Genesis presents itself is the way Scripture reads it and there is no other interpretation. With that, there is a singular hermeneutical mindset about this passage in Scripture. And that clarity punctuates why the doctrine of creation matters. God wanted this truth understood. This is not a doctrine that is hidden (cf. Deut 29:29) or even one that has components that await further elucidation by later revelation (cf. I Pet 1:10-12). Rather, this doctrine was originally presented in no uncertain terms, and the rest of Scripture maintains such clarity by reiterating the same ideas repeatedly without modification. Scripture then does not view its teaching on origins as a mystery or something to be nuanced or qualified. Instead, it views this doctrine as so clear that the rest of Scripture assumes the reader understands it. Consequently, one cannot avoid it or neuter its forcefulness by appealing to its supposed ambiguity. This is a doctrine that is to be known in the way that all Scripture knows it. It is definable and thereby definitive.

\section{What is at Stake in the Doctrine of Creation?}

At this point, one can see why theology is queen of the sciences and that the doctrine of creation is clear. A lingering question still might be whether the doctrine carries great importance. One may allege that though the scriptural assertions of creation are clear, some flexibility should be offered because creation is not an essential doctrine. In some people's minds, because creation is not that crucial, varying viewpoints on this view offer little danger to the faith. Put differently, is there really anything at stake with the doctrine of creation?

To be sure, pastorally, one should have great patience with people as they grow into the truth (cf. 2 Tim 4:2). This is not just for the doctrine of creation but for any doctrine or addressing any sin. Nevertheless, that is a completely different issue than whether the doctrine of creation is crucial. As noted, creation is at the beginning of God's story of this world and the genesis of His revelation of theology. Change something at the beginning, and the ripple

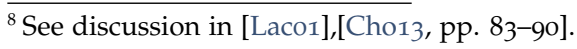


effect is found throughout the rest. Replace the framework of creation with a different one (like evolution) and if one holds it consistently, a reworking of theology takes place. That is what this particular discussion endeavors to demonstrate. Using the ten major categories of systematic theology, one can observe that the distinctive activity of creation described in Genesis undergirds the breadth of Christian doctrine. Creation is far from an isolated truth. It is at the beginning and thereby at the foundation of it all.

\section{Theology Proper, Christology, and Pneumatology}

For instance, one could begin by examining the doctrines of theology proper as well as Christology and Pneumatology. One aspect of God's distinctiveness is the fact that He creates. Scripture assigns God the unique role of Creator and everything else as created. This is not only God the Father but includes the second person of the Trinity and the Spirit. The Spirit hovers over the waters (Gen 1:2); He affects creation directly. And when Scripture desires to demonstrate the deity of Christ, it appeals to His role in creation (Jhn 1:1-2; Col 1:16). Within this, Scripture defines the manner in which God creates. The Hebrew word for create (ברא) is used uniquely with God as subject and is not the same term as "make" (עשה) or "form" (יצר) which can be used with human subjects [Sch97]. While "making" and "forming" stress how one makes a product from already existing material, the verb "create" emphasizes the personal and direct intervention of God to produce that which is distinctively other than what had existed [Sch97]. For example, David desires the Lord to create in him a clean heart (Ps 51:10), which is categorically different than what was present in the psalmist. Likewise, God creates praise in people who were rebellious; He produces a work in their lives that was otherwise non-existent (Isa 57:19). Creation is the exclusive act of God, and such involved and creative acts do not just extend to the creation of the cosmos ex nihilo, ${ }^{9}$ but also to particular things including animals (Gen 1:21) and people (Gen 1:27) which all specifically involve the term ברא. The logic of Scripture is that because God created in such direct fashion, He is directly over His creation (cf. Isa 40:26, 28; 42:5; 45:12). He claims total and pure authority over all He has created because nothing else can receive credit for the existence of that entity [Sch97, Smio9, Osw98]. However, if evolution is true, then a different set of events exist than what the Genesis account describes. At minimum, intermediary causes were involved in the generation of animals or humans or the entire world. If that is the case, then the very distinctiveness, otherness, and authority of God must be redefined.

One can add a further note on the ramifications of changing the doctrine of creation on the doctrine of God. It not only shifts His distinctiveness but also His character. If one attempts to harmonize evolution with Genesis 1-3, then death happened before the Fall. After all, death

9 Theologians argue for creation of the world from nothing is rightly based upon how the word is used in the context of Genesis 1-2 [Sch97],[Mat96, p. 129]. 
is an inherent part of the evolutionary mechanisms that generated this world. The Fall only takes place after everyone is made. Accordingly, God declares that a world with death is good and very good (Gen 1:31). Death itself then is something that is good. That changes the very definition of God's goodness. A shift in one's understanding of creation consistently shifts one's viewpoint on God's (in all three persons of the Godhead) otherness as well as the definition of His attributes.

\section{Anthropology}

If the biblical account of creation is not historical, then the category of anthropology must change. For one, the distinction between man and animal is blurred. In Genesis, man is created in the image of God and in an entirely different manner than animals (Gen 2:7). This elevates man over creation (cf. Gen 1:28-30) to have dominion over it. However, if evolutionary thought is true, then man originates from animals and the distinction between people and animals is not as sharp, if present at all. Likewise, biblical anthropology argues that there are two biological sexes for man, male and female. That too is based upon the creation narrative (Gen 1:27). In fact, later discussions of sexual morality will use terms from the creation account to anchor ethics in what God did in creation. ${ }^{10}$ However, if the account of creation did not occur, then the idea of male and female has no actual grounding and as a result, biblical ethics about human sexuality come undone. In addition, the unity of the humanity is predicated upon creation. The idea that man is one is because people all descend from one father, Adam (and later on Noah; cf. Acts 17:26) [Boco7]. However, if this is not historical, then that unity has no true basis. The truth that people are ultimately of one family and should not act in partiality against one another has no foundation in reality. If one changes the origins of man, one changes a great deal of the category of anthropology and its ethical demands.

\section{Ecclesiology}

If a shift in the doctrine of creation changes the doctrine of man, it also will equally affect the doctrine of ecclesiology or the church. A critical component of the church is that the church is a new humanity in Christ (cf. Eph 2:15) [Thi1o, p. 170]. The significance of the unity within the church demonstrates that the gospel can overcome the effects of sin and the fall, the most obvious being how man is fractured and divided though actually one. ${ }^{11}$ However, if the evolutionary account is true, humanity does not necessarily originate from a single head. If

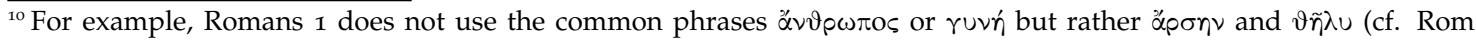
1:26-27) which correspond to the Greek translation of Genesis 1:26-28. The same occurs in Galatians 3:28 which

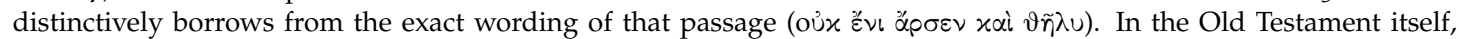
Leviticus 18:22 does not use the more common root ארם for man but rather זָכָר which goes back to Genesis 1:27.

${ }^{11}$ See later discussion for further explanation.
} 
evolution is at all true, the church demonstrates a unity humanity never had nor was intended to have. If evolution is at all true, a major theological significance of the church falls apart.

\section{Hamartiology}

A shift in the doctrine of creation would also affect hamartiology or the doctrine of sin. For one, as mentioned, creation is what grounds why particular sins are wrong (cf. Lev 18:22; Rom 1:26-27). A change in the doctrine of creation would remove the ground from certain ethical imperatives and thus alter the doctrine of sin. Moreover, one's categorization of good and evil also should be modified if the creation narrative is reinterpreted. Scripture, since the beginning, has associated death with sin and evil (cf. Gen 2:17). It is something to be overcome as opposed to something that should be promoted (Heb 2:14-15). However, if an evolutionary backstory is adopted, death came before the Fall and is actually "good" in that it facilitates natural selection. If one changes the foundation of creation, the definitions of what is good and evil necessarily shift as we begin calling good what the Bible labels as evil. On top of this, the very scope and existence of evil are brought into question. The creation account provides the exact method of how sin came into the world (Gen 3:1-7) and shows how it affected the whole world (Gen 3:8-19). This thought presumes the existence of a perfect world, Adam, a tree of the knowledge of good and evil, Adam's headship over humanity, and his disobedience. But if, per an evolutionary mindset, these things are myth and something else took place, then there is no true accounting for why evil is in this world, or if sin is universal among mankind or creation, or if it exists at all. In fact, given how death would have to be recategorized morally, perhaps good and evil do not truly exist as absolute moral categories with an evolutionary grounding of origins. Accordingly, sin both in particular and in category would be redefined if the doctrine of creation changes.

\section{Soteriology}

The doctrine of salvation would also be affected by a change in creation. After all, salvation is depicted as an act of creation. David cries out for God to create in him a new heart (cf. Ps 51:10). However, if "creation" is really just "evolution," then what does salvation exactly do and produce in one's life? Similarly, believers are called a new creation in Christ (cf. 2 Cor 5:17). However, if creation never truly occurred as Scripture describes, then what does a new creation denote? Furthermore, if, in any derivative of an evolutionary model, origins already included things like death, what does being a new creation mean? The very metaphors of salvation are distorted and undermined if the doctrine of creation shifts. These are not just theoretical questions since Paul himself discusses God's act of creating light from nothing to show how God creates spiritual light in the darkened heart (cf. 2 Cor 4:6). Likewise, Paul parallels condemnation in Adam with salvation in Christ (Rom 5). In these contexts, Paul's 
logic sets creation and the act of salvation in parity. One is based upon the other. Accordingly, if creation did not historically occur the way Paul and Scripture describe, then the very logic and operation of salvation falls apart. This is of no small consequence to the category of soteriology.

\section{Eschatology}

Changes at the beginning alter the end. This is supported by the very language of new creation along with the language of a new heavens and earth (cf. Isa 65:17; 2 Cor 5:17; Rev 21:1), all of which parrot the original creation of heaven and earth in Genesis 1:1. Cosmology is tied with eschatology. However, if God never technically created to begin with, the definition of creation changes, and the definition of a new creation will change as well. If historically God originally created the paradise of Eden with death in a good world, why would one expect any different in the final creation? One might argue that the new heavens and earth are different because the Bible says so (Rev 21:4). However, harmonization with evolution raises serious questions to such descriptions. After all, if Scripture established that original creation was without death even though that was not the case, what grounds does one have to say any different about the end, especially when Scripture explicitly relates the two? With that, the very core of Christian hope of how God deals with sin and death is shaken if one consistently upholds a change in the beginning.

\section{Angelology}

There is also the category of angelology. One might think that an alternative understanding of creation would have little impact on this area of theology. However, in Job 38:7, God Himself recounts that the angels beheld and rejoiced over how He set the formation of the dry land (Job 38:3-6). If God did not directly create as Genesis specifies or if an evolutionary history is what actually happened, then this specific fact about angels is false. Even the doctrine of angelology is affected by the doctrine of creation.

\section{Bibliology}

The tenth and final category remaining is bibliology and to be sure, one's position on creation and its potential harmonization with evolution will affect this. In light of redrafting the major categories of theology and all the passages therein, this is a redefining of the entire Bible, a matter of bibliology for sure. And that brings up what was discussed prior; namely, this entire discussion ultimately pertains to a discussion on how one understands biblical inspiration, inerrancy, and authority, as well as how these doctrines interact with accommodation and human observation [Lam13, pp. 48-53],[Grui7]. They deal with the nature of truth and 
the hierarchy of certainty and truthfulness between special revelation and what one derives from "natural theology." Such questions are a matter of the very substance of the category of bibliology, and so the way one answers the question of evolution and creation has bearing upon this area of theology [Grui7, p. 821].

The ABOve Discussion illustrates how each major category of systematic theology shifts if one incorporates evolution into the creation narrative and remains consistent with that. To be clear, this is not an allegation that those who contend for theistic evolution or other derivatives of accommodation or harmonization actually embrace these ramifications (although some do). ${ }^{12}$ Rather, the point is that logical consistency demands these consequences. And such consequences radically shift the major tenets that summarize Christian dogma, that which distinguishes Christianity as Christianity theologically. Thus, what is at stake with the doctrine of creation is nothing short of Christianity itself. And that demonstrates why the doctrine of creation matters. It is not an isolated doctrine that has little effect on the rest of Christian teaching. ${ }^{13}$ Rather, it is a doctrine that is at the beginning, thereby fundamental, and interwoven with the foundation of the chief aspects of Christian thinking. The doctrine of creation is one that cannot be ignored. If theology is the queen of the sciences, then creation is inextricably linked with that.

\section{The Significance of Creation}

The doctrine of creation has the backing of divine authority, clarity from God's revelation, and is inextricably linked to the theology of Scripture. However, is there any significance to that? If it is part of the queen of the sciences, does it offer any value to the sciences? The following discussion shifts from what is at stake theologically concerning creation to the significance it has. There is a reason that creation is so entrenched hermeneutically and theologically in Scripture. It is because the doctrine of creation drives the very redemptive agenda of God in the storyline of Scripture. In essence, one could sum up the forcefulness of the doctrine this way: creation teaches that this is our Father's world, everything in it is for His glory, and so He will make all things right in the end. That theology is not only a dominant driving logic in redemptive history, but is also at the heart of the answer to the major questions people have about this world. It thereby provides the underpinning logic for the beauty and telos of the sciences. The significance of the doctrine of creation is weighty.

\footnotetext{
${ }^{12}$ See [Lam13, p. 58]. Lamoureux states, "Obviously, this conclusion challenges the traditional doctrine of original sin. Yet this is unsurprising, since it was formulated by anti-evolutionist and scientific concordists such as church father Augustine (364-430)" (footnote 32). Some in fact do hold to the ramifications listed above.

${ }^{13}$ See [Gru17, p. 821]. Note Grudem's statement: "Theistic evolution is not at all a harmless 'alternative opinion' about creation but will lead to a progressive erosion...."
} 
An effective way to observe all of this is to survey from Genesis to Revelation. Within this, we can show how various points of redemptive history tie back to creation and display how creation drives God's plan in resolving all things.

In tracing this, it is appropriate to begin at the beginning. And the creation account itself teaches the fundamental concept that this is our Father's world, everything in it is for His glory, and He will make all things right. Each of these ideas is found within the opening chapters of Genesis. Fundamentally, Genesis 1 declares that this is God's world. The first chapter of Genesis is structured around the different locales of light and dark (Gen 1:3-5), sky and sea (Gen 1:6-8), and the land (Gen 1:9-13). It then progresses to describe how God fills each of these locales: sun, moon, and stars for the light and dark; animals in the sky and sea; and then animals along with man for the land [Mat96, p. 144]. The very structure of Genesis 1 shows that God controls every place and everything that fills those places. This is our Father's world. Furthermore, the text demonstrates that all is for His glory. God says that this creation is not just good but very good. God also sets the world apart for himself on the Sabbath day as He makes it holy unto Himself (Gen 2:3) [Ham9o, p. 143]. With that, the whole world is consecrated for His honor. On top of all this, the initial chapters of Genesis teach that because He is over this world and it is for Him, He will make all things right. In Genesis 3, the Fall occurs but God has always had a plan. In Genesis 3:15 God specifically reveals that His Son, the Messiah, will ultimately crush the serpent's head. This begins God's agenda of redemption. Accordingly, Genesis 1-3 collectively establish that this is our Father's world, everything in it is for His glory, and He will make all things right in the end.

This agenda is not merely declared at the beginning of the story but carried out on a global scale. The worldwide Flood demonstrates this. To be sure, the event exhibits God's wrath in global destruction. At the same time, it is pertinent to observe that there are several parallels between Genesis 8 and creation. For example, in Genesis 8:1, the waters ascend above the mountains and to the point such that there is only sky and sea. The scene is reminiscent of creation (cf. Gen 1:2). In Genesis 8, there is a "wind" over the waters which sounds like the language of Genesis 1:2 where the "Spirit" (the same word as "wind" in Hebrew) hovers or blows over the waters. In Genesis 8, the text recounts how the dry land appears like was said in Genesis 1:9. Later on in Genesis 8:17, the text says, "be fruitful and multiply," which is found in Genesis 1:28. Repeatedly, the Flood narrative links back with creation. It evidences that God is following through on His agenda established at creation. The Flood, while judgment, is part of God's plan to restore things back to the way they ought to be. For this reason, God establishes the Noahic covenant (Gen 9:1-7). The term Noah means "rest," and such rest is associated with Edenic rest, for the first time the root word occurs is in Genesis 2:15 which discusses that very reality [Mat96, pp. 208, 316-18]. With that, God's agenda about creation is not merely theoretical; rather, while He judges the entire world, He also positions it toward Edenic rest. He will make all things right. 
This agenda continues beyond the book of Genesis into Exodus. Within that book, the plagues themselves illustrate God's control over creation. This is not merely conceptual. There are some deliberate links between the two. In the ten plagues, there are three sets of three plagues dealing with the water (Exod 7:14), the land (Exod 8:20; 9:1), and the sky (Exod 9:13; 10:1, 21). Those are the very categories that occur in Genesis 1 in the first three days of creation. In addition, the ten plagues use distinct language, such as "swarming," found in Genesis 1 (Exod 8:3; cf. Gen 1:20). These allusions indicate that God's work of creation and the plagues are tied together. It is the Lord's declaration to Egypt and the entire world that He, and not the gods of Egypt (cf. Exod 12:12), is Creator and that He has an agenda to make all things right.

Such a context accounts for the details of another item in the book of Exodus: the Tabernacle. The very construction of the tabernacle resembles creation and Eden with, for instance, the blue tent representing the sky (Exod 26:1) [Beao4]. However, even the way the instructions for the Tabernacle is organized connects back with creation. The instructions repeat the language

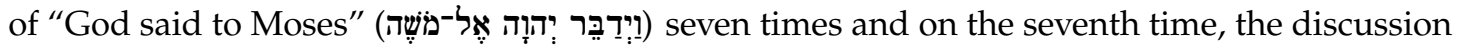
is about the Sabbath (Exod 25:1; 30:11, 17, 22; 31:1; cf. 30:34; 31:12). The resemblance to the seven days of creation week where the seventh day is the Sabbath is striking [Kliz7, Saiog]. The description of the tabernacle both in the building itself and even its literary presentation points the reader back to creation. God announces in the Tabernacle that while one is separated from God because of sin, there will be a day when man will be reunited with Him like in Eden. This not only reiterates the creational agenda but demonstrates that it does not apply to creation generically, but rather in details including worship.

Along that line, another item in Exodus goes back to creation: the Ten Commandments. There are numerous connections between creation and these imperatives. The first two commandments certainly uphold what God demonstrated at creation: He is the only true God and Creator, everything else is creation, and thus one should not confuse the creation with the Creator. The tenth commandment about coveting borrows language from Genesis 3 where the woman desired the fruit (cf. Gen 3:6). ${ }^{14}$ And the fourth commandment concerning the Sabbath directly connects back to God's work at creation. The connection of the Ten Commandments back to creation reflect that the holiness God instituted at original creation is still the standard and Israel is to announce this to the world as a kingdom of priests (Exod 19:6). The world will not merely be made right physically, but rather its moral beauty and holiness will also be restored. God truly will make all things right.

Such an emphasis of holiness moves to the book of Leviticus. Within this, God states that when His holiness is fulfilled and Israel finally becomes a holy people, they will be His people and He will be their God. Within this, Leviticus 26:12 declares that God will walk amongst

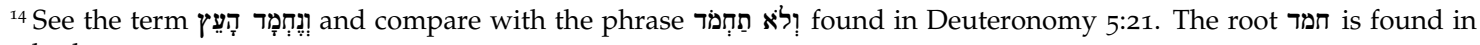
both. 
His people. The language distinctively goes back to when God walks amongst Adam and his wife in the garden. Again, God will restore the world back to Eden. And such a restoration will be comprehensive, for it will even redeem man's relationship with God. They will never be lonely again but commune with God like Adam and his wife did in the garden.

Later books reveal the extensive nature of God's sovereignty over all things as Creator and thereby His determination to make all these things right. First Kings 4 is a good example of this. That account lists the food the household of Solomon consumes in a day. In examining this list, it is interesting that only one other place in the entire Bible lists the same animals: Deuteronomy 14. That earlier passage presents the clean foods which Israel may eat when they enter the land. Initially, this confirms that Solomon's kingdom is an indication of how Israel was enjoying the promises that God has for them. However, it goes beyond this. Deuteronomy 14 has the language of "you may eat any..." (cf. Deut 14:11, 20), which is very similar language to what God said in the garden to the man (cf. Gen 2:16) [Tig96]. This implies that Deuteronomy itself has ties back to creation and because 1 Kings 4 is connected with Deuteronomy, it too has these ties. The bounty of Solomon's kingdom reflects not only the working out of God's promises for Israel but the working out of God's plan to restore what was available in the garden of Eden [Demo3]. One day, there will be a time when creation is so restored that even its food supply will be plentiful and there will be no hunger. The prophets themselves tell of this (cf. Joel 3:18; Amos 9:14-15).

Speaking of which, the prophets themselves expound upon God's creational agenda. Isaiah I1 says that the lamb will lay down with the wolf, and the bear will eat grass. Genesis establishes that God directly created the animals (Gen 1:20-25), He is thereby sovereignly over them, and therefore He will even make that aspect of creation right in the end. It goes beyond this. In Psalm 51, David prays for God to create in him a clean heart (Ps 51:10). With that, God's creational agenda does not merely deal with things that are external and physical but even that which is spiritual and internal. This too will be rectified because God is over all His creation, both physical and spiritual.

While much more could be said of the Old Testament, a focal point of God's creational agenda occurs in the book of Daniel. In the center of the book, Daniel has a vision of the sky and the sea, animals, and one like a son of man who rules over them all (cf. Dan 7:1-13). Such a progression mirrors Genesis 1 [Laco1]. The vision demonstrates that what is true at the beginning will be true at the end. This is the very substance of God's creational agenda discussed thus far. However, the one at the center of the vision is the one like a son of man, the second person of the Trinity, the Lord Jesus Christ (cf. Dan 7:9-13). ${ }^{15}$ He is the final Adam (cf. Rom 5:12) and will be the ultimate ruler of when God makes all things in His creation right. Thus, the Old Testament shows not only the exhaustive ramifications of God's work of

\footnotetext{
${ }_{15}$ See discussion in [Cho13, pp. 131-39].
} 
salvation but also its exclusivity. It all revolves around and centers upon His Son. All of this directly goes back to Genesis 1 and its design therein. God is Creator over all His creation and set one man over it all to rule it. Therefore, God, as Creator, will make all things right in His creation and set the God-man, His Son, to rule over it all in the end. The Old Testament has reiterated God's agenda, covered it from a host of angles, and focused it upon Christ.

Such focus compels the storyline to move from Old Testament to New Testament. In the gospels, Jesus repeatedly calls Himself the Son of Man (Matt 8:20; 9:6; Mark 10:45; Luke 9:26; 19:10; Jhn 13:31) to accentuate that He is the final Adam prophesied in Daniel (cf. Luke 3:38). He has come to make all things right. And His miracles attest to this as He controls every element of this universe including plants (Jhn 2:1-12), the sea (Jhn 6:15-25), people (Matt 9:113), and even death (Mk 5:21-43). These signs, as the apostle John asserts, serve as a reminder that truly Jesus is the Creator, for in the beginning was the Word, and Jesus is that Word (Jhn 1:1). So Christ's miracles demonstrate that Jesus is the Creator and how He has the sovereign might to restore things in His kingdom. Ultimately, our Lord's death and resurrection are what secures this very restoration. He rises from the dead on the third day which is the first day of the week (Jhn 20:1). The emphasis on the first day of the week is significant, for it parallels the first week of creation. Christ's resurrection begins a new era of creation. That is further supported by how the Lord is described post-resurrection. Mary mistakes Him to be a gardener (Jhn 20:15), an allusion to Adam the first gardener (Gen 2:8) [Kö9]. The timing and description of the resurrection are meant to parallel creation and show a new creation. Put simply, John's gospel begins with creation in the beginning and it ends with a new creation. With that, the New Testament demonstrates that God's creational agenda does not divert from what was established in the Old Testament, but rather climaxes, secures, and fulfills it.

The New Testament continues to show the ramifications of what it means that God will restore things to original creation. In Acts 2, at the birth of the church, there is language of creation associated with this new institution. The term "wind" found in Acts 2:2 ( $\pi \nu$ on $s$ ) is a rare term in both the New Testament and the Greek translation of the Old. It is strictly associated with how God breathes in man the breath of life (Gen 2:7). With such language, Luke portrays the creation of the church like the creation of man, and the church then is a new humanity. This accords with the new creational work done by Christ, the final Adam, in the gospels, as well as with what Paul later says about the church as "one new man" (Eph 2:15) [Thi1o, p. 171], [Lingo]. This is also reflected in the apostle's language of believers being a new creation (2 Cor 5:17) [Mar68, Haro5]. Within this, in Acts 2, the church speaks in tongues. Given that the context is steeped in references to Genesis, speaking in tongues makes such a connection as well. It alludes to the first time the world ever spoke in tongues, which occurs in Genesis 11 at the Tower of Babel. There, man rebelled against God and He scattered them by dividing their language. Here, in Acts, man speaks in tongues because he has come back to God and God unites them. This new humanity is not merely transformed from the heart 
but also united, something that has not happened since the Tower of Babel. The church is the proof that God will overcome sin and its effects, even the most pervasive ones. Accordingly, God will not only restore the physical world, animals, and one's heart. He will even work such that there will be a new humanity united under a new Adam. Every detail and intent of original creation will be upheld. And that provides hope even for the question of whether there will ever be world peace. There will be because this is our Father's world and He will make all of it right for His glory.

The church's job is not merely to be transformed as part of God's creational agenda but to point to the fulfillment of that agenda. Since the church is a first fruit of a new creation (Jas 1:17), they attest to a time for which creation groans (Rom 8:19-20); namely, when it will be set free from its slavery to corruption (Rom 8:21). So the church looks forward to where redemptive history is moving: when the Father will make all things in His world right. For this reason, as described in Revelation, God will eschatologically unleash a series of judgments. These acts of wrath have parallels to the creation week as the grass ( $\operatorname{Rev} 8: 7)$, water $(\operatorname{Rev} 8: 9)$, and sky are affected (Rev 8:10) [Bea99]. God's judgment is in a sense a de-creation to rebuild all things as He originally intended them to be. The complete proof of that occurs after Christ's reign for a thousand years when Satan is released. Satan goes out to deceive the nations as he originally deceived Eve. Such a parallel shows that the point of this event is to answer the question: having restored the world, could the Fall ever happen again? However, unlike in Genesis 3 when Adam disobeyed and the world plunged into sin, the final Adam will never fail and so the redeemed world will never plunge into sin again. With that, God has made all things right and dealt with evil in such a way that accounts for everything - both individual issues as well as even the category of whether the Fall could ever happen again. In doing so, He has solved the problem of evil. And at that future moment, it is clear that this is the Father's world, everything in it must be for His glory, and so He has made all things right in the end.

THIs Discussion HAs commented on how God makes all things right, things that include the physical creation, morality, one's relationship with God, food and hunger, loneliness, one's spiritual heart, sin, the dysfunction of humanity, and evil itself. These are major questions people have concerning life and even ask about Christianity. Scripture does not shy away from these issues. Rather, the Bible has answers to these questions and the formulation of these answers revolves around creation. Because God has created this world for His glory, He will restore it all back to right. Redemptive history fleshes out the extent of this redemption, and it indeed is exhaustive. Put simply, every question people have about this world is answered by the doctrine of creation, for that doctrine declares that God is over this world. The doctrine of creation is foundational to answering the most pressing questions people have.

All of this, though, presumes that creation took place a certain way. It presumes God's 
direct act of creation and direct ownership of every part of it. It presumes that the created world existed in a certain state. It presumes that His creation was truly very good. If any of these presuppositions, established in Genesis itself, fall apart, then the entire logic of this full redemption falls apart. This highlights another danger of accommodation to evolution. It will undermine the very hope and resolution Christianity declares. However, more to the point, instead of being a liability to the veracity of Christianity, the doctrine of creation is actually one of its greatest assets. For in it is the grounds of why God does what He does and why we can have hope. We believe that all things can be dealt with because God had created a creation that was very good and not filled with death or decay. Since He is perfect and can make perfect things, He will do so in the end. Creation is not merely a doctrine of the past but a doctrine about the future. With that, as the queen of the sciences, theology and creation do not merely provide an authoritative framework for science, they also provide it with wonder, beauty, and hopefulness. For now, in this doctrine, science is the constant observation that this is our Father's world, everything in it is for His glory, and He will make all things right in the end.

\section{Conclusion}

Modernist thought has been skeptical about the primacy of theology, and in this culture Christians have often thought of creation as a tertiary matter of little consequence. However, there is a reason that in the past theology was known as the queen of the sciences. Human reasoning, while impressive, can never trump divine revelation. Man is nothing in comparison with the infinite omniscient Creator of the universe. Job compellingly articulates this:

The departed spirits tremble

Under the waters and their inhabitants.

Naked is Sheol before Him,

And Abaddon has no covering.

He stretches out the north over what is formless

And hangs the earth on nothing.

He wraps up the waters in His clouds,

And the cloud does not break out under them.

He obscures the face of His throne

And spreads His cloud over it.

He has marked a circle on the surface of the waters

At the boundary of light and darkness.

The pillars of heaven tremble

And are astonished at His rebuke.

He quieted the sea with His power,

And by His understanding He crushed Rahab.

By His breath the heavens are made beautiful; 
His hand has pierced the fleeing serpent.

Behold, these are the fringes of His ways;

And how only with a whisper of a word do we hear of Him!

But His mighty thunder, who can understand? (Job 26:5-14)

God has created and runs the world that science discovers. Job declares that what is mysterious and puzzling to man, God established and knows. And what is astonishing is that the above list of God's dominion over the natural and supernatural is just "the fringes of His ways... a whisper of a word..." What man endeavors to comprehend is the smallest sliver of God's total knowledge. And all of this should humble man and reinforce that his knowledge is not as comprehensive or certain as he might think. Accordingly, what God has inerrantly revealed in Scripture is the complete, certain, and absolute truth. It stands far above what fallible, finite, and sinful man may derive. And this discussion has shown that, within this revelation, the doctrine of creation is not only clearly expressed but an inextricable part of the theology of Christianity. Far from being subordinate or irrelevant to man's thinking, theology—specifically creation-is categorically above all human thought. It is the queen of the sciences.

It IS FITTING to discuss the issue of creation in the inaugural issue of a journal designed to explore the sciences from a Christian worldview. Starting points matter. And for science to be done right and to be used right requires that it starts right. And the doctrine of creation is that starting point. For this doctrine establishes why the sciences even exist and should have a crucial place in our study and society. The sciences engage in the discovery of all that is in our Father's world. Their purpose is to illustrate how truly everything has been created for His glory. And though science will observe the fallenness of this world, because it continues to illustrate how this is our Father's world, it points to the truth that God will make all things right. This is true science, one that is done according to truth, filled with worship, and offering true hope. Creation does not hinder science but recovers the nobility of science. It then cannot be an afterthought but the first thought for the sciences.

\section{Bibliography}

[Ald93] Robert L. Alden. Job, pages 274-75. The New American Commentary, Vol. 11. Broadman \& Holman Publishers, Nashville, TN, 1993.

[Bau83] Richard J. Bauckham. 2 Peter, Jude, page 213. Word Biblical Commentary, Vol. 50. Word, Incorporated, Dallas, TX, 1983.

[Bea99] G. K. Beale. The Book of Revelation: A Commentary on the Greek Text, pages 450-51, 486. The New International Greek Testament Commentary. Eerdmans Publishing, Grand Rapids, MI, 1999. 
[Beao4] G. K. Beale. The Temple and the Church's Mission: A Biblical Theology of the Dwelling Place of God. InterVarsity Press, Downers Grove, IL, 2004.

[Beao6] G. K. Beale. Myth, history, inspiration: A review article of inspiration and incarnation by Peter Enns. Journal of the Evangelical Theological Society, 49(2):287-312, 2006.

[Boco7] Darrell Bock. Acts, page 566. Baker Exegetical Commentary on the New Testament. Baker Books, Grand Rapids, MI, 2007.

[Boyo8] Steven Boyd. The genre of Genesis 1:1-2:3: What means this text? In Terry Mortenson and Thane Ury, editors, Coming to Grips with Genesis, pages 163-92. New Leaf Publishing, Green Forest, AK, 2008.

[Bru64] F. F. Bruce. Commentary on the Epistles to the Hebrews, page 44. New International Commentary on the New Testament. Eerdmans Publishing, Grand Rapids, MI, 1964.

[Cas61] Umberto Cassuto. A Commentary on the Book of Genesis. Hebrew University, Jerusalem, 1961.

[Cho13] Abner Chou. I Saw the Lord: A Biblical Theology of Vision. Wipf \& Stock Publishers, Eugene, OR, 2013.

[Cho14] Abner Chou. "Did God really say?"- hermeneutics and history in Genesis 3. In Abner Chou, editor, What Happened in the Garden: Reality and Ramifications of the Creation and Fall of Man. Kregel, Grand Rapids, MI, 2014.

[Cho16] Abner Chou. Is inerancy inert? Closing the hermeneutical 'loophole': Inerrancy and intertextuality. In John MacArthur, editor, The Inerrant Word: Biblical, Historical, Theological, and Pastoral Perspectives, pages 231-43. Crossway, Wheaton, IL, 2016.

[DBoo] Frederick William Danker and Walter Bauer. A Greek-English Lexicon of the New Testament and Other Early Christian Literature. University of Chicago Press, Chicago, IL, 2000.

[Demo3] Stephen G. Dempster. Dominion and Dynasty: A Theology of the Hebrew Bible, pages 147-50. New Studies in Biblical Theology. InterVarsity Press, Downers Grove, IL, 2003.

[Ell93] Paul Ellingworth. The Epistle to the Hebrews: A Commentary on the Greek Text, page 91. Eerdmans Publishing, Grand Rapids, MI, 2nd edition, 1993.

[Enn11] Peter Enns. Ecclesiastes, page 42. Two Horizons Old Testament Commentary. Eerdmans Publishing, Grand Rapids, MI, 2011.

[Fut98] Mark D. Futato. Because it had rained: A study of Genesis 2:5-7 with implications for Genesis 2:4-25 and Genesis 1:1-2:3. Westminster Theological Journal, 60:1-21, 1998.

[Gato2] Simon J Gathercole. A law unto themselves: The Gentiles in Romans 2.14-15 revisited. Journal for the Study of the New Testament, 85:27-49, 2002. 
[Gro85] Jakob H. Gronbaek. Baal's battle with Yam-a Canaanite creation fight. Journal for the Study of the Old Testament, 33:35, 1985.

[Grui7] Wayne Grudem. Theistic Evolution Undermines Twelve Creation Events and Several Crucial Christian Doctrines, pages 821-22. Crossway, Wheaton, IL, 2017.

[Ham9o] Victor P. Hamilton. The Book of Genesis Chapters 1-17. New International Commentary on the Old Testament. Eerdmans Publishing, Grand Rapids, MI, 1990.

[Har88] John E. Hartley. The Book of Job. Eerdmans Publishing, Grand Rapids, MI, 1988.

[Haro5] Murray J. Harris. The Second Epistle to the Corinthians, pages 432-33. The New International Greek Testament Commentary. Eerdmans Publishing, Grand Rapids, MI, 2005.

[HYoo] W. W. Hallo and K. L. Younger. Context of Scripture. Brill, Leiden, 2000.

[Jono3] Taylor B. Jones. Why a scriptural view of science? In John MacArthur and Richard L. Mayhue, editors, Think Biblically! Recovering a Christian Worldview, chapter 7, pages 232-35. Crossway, Wheaton, IL, 2003.

[Kög] Andreas J. Köstenberger. A Theology of John's Gospel and Letters. Zondervan, Grand Rapids, MI, 2009.

[Kid] Derek Kidner. Psalms 73-150. Tyndale Old Testament Commentary.

[Kid67] Derek Kidner. Genesis. InterVarsity Press, Downers Grove, IL, 1967.

[Kli58] Meredith G. Kline. Because it had not rained. Westminster Theological Journal, 20:14657, 1958.

[Kliz7] Meredith G. Kline. Investiture with the image of God. Westminster Theological Journal, 4O(1):41, 1977 .

[Laco1] André Lacocque. Allusions to creation in Daniel 7. In John Joseph Collins, Peter W. Flint, and Cameron VanEpps, editors, Book of Daniel Volume One, pages 114-31. Brill, Leiden, 2001.

[Lam92] W. G. Lambert. Enuma Elish. In David Noel Freedman, editor, The Anchor Yale Bible Dictionary, D-G: Vol. 2. Doubleday, New York, NY, 1992.

[Lam13] Denis O. Lamoureux. No historical Adam: Evolutionary creation view. In Ardel B. Caneday and Matthew Barrett, editors, Four Views on The Historical Adam. Zondervan, Grand Rapids, MI, 2013.

[Lan91] William L. Lane. Hebrews 1-8, page 10. Word Biblical Commentary, Vol. 47A. Word, Incorporated, Dallas, TX, 1991.

[Lan92] William L. Lane. Ecclesiastes, page 18. Word Biblical Commentary, Vol. 23A. Word, Incorporated, Dallas, TX, 1992. 
[Lingo] A. T. Lincoln. Ephesians. Word Books, Dallas, TX, 1990.

[Lon12] Tremper Longman. Job, pages 31-32. Baker Exegetical Commentary on the Old Testament. Baker Academic, Grand Rapids, MI, 2012.

[Mar68] R. P. Martin. 1 and 2 Corinthians. Eerdmans Publishing, Grand Rapids, MI, 1968.

[Mat96] Kenneth A. Matthews. Genesis 1-11:26. New American Commentary, Vol. 1A. Broadman \& Holman Publishers, Nashville, TN, 1996.

[Mey17] Stephen Meyer. Scientific and philosophical introduction: Defining theistic evolution. In J. P. Moreland et al., editors, Theistic Evolution: A Scientific, Philosphical, and Theological Critique, pages 33-44. Crossway, Wheaton, IL, 2017.

[MM17] John MacArthur and Richard L. Mayhue, editors. Biblical Doctrine: A Systematic Summary of Bible Truth. Crossway, Wheaton, IL, 2017.

[Moro3] Brian Morley. Understanding our postmodern world. In John MacArthur and Richard L. Mayhue, editors, Think Biblically! Recovering a Christian Worldview, chapter 7, pages 136-139. Crossway, Wheaton, IL, 2003.

[Mor17] J. P. Moreland. Why science needs philosophy. In J. P. Moreland et al., editors, Theistic Evolution: A Scientific, Philosphical, and Theological Critique, pages 553-55. Crossway, Wheaton, IL, 2017.

[Osw98] John N. Oswalt. The Book of Isaiah Chapters 40-66, pages 66-67. New International Commentary on the Old Testament. Eerdmans Publishing, Grand Rapids, MI, 1998.

[Rey98] Robert Reymond. A New Systematic Theology of the Christian Faith. Thomas Nelson Publishers, Nashville, TN, 2nd edition, 1998.

[Roo92] Mark F. Rooker. Genesis 1:1-3: Creation or re-creation? Bibliotheca Sacra, 149(596), 1992.

[Saiog] J. H. Sailhamer. The Meaning of the Pentateuch: Revelation, Composition, and Interpretation. IVP Academic, Downers Grove, IL, 2009.

[Sch97] W. H. Schmidt. ברא. In Ernst Jenni and Claus Westermann, editors, Theological Lexicon of the Old Testament, Vol. 1, page 255. 1997.

[Scho3] Thomas R. Schreiner. 1, 2 Peter. Broadman \& Holman Publishers, Nashville, TN, 2003.

[Smiog] Gary V. Smith. Isaiah 40-66, page 166. New American Commentary, Vol. 15B. Broadman \& Holman Publishers, Nashville, TN, 2009.

[Steo2] Andrew E. Steinmann. אחד as an ordinal number and the meaning of Genesis 1:5. Journal of the Evangelical Theological Society, 45(4):577-84, 2002. 
[Thi1o] Frank Thielman. Ephesians. Baker Exegetical Commentary on the New Testament. Baker Books, Grand Rapids, MI, 2010.

[Thoo2] Robert L. Thomas. Genre override in the gospels. In Robert L. Thomas, editor, Evangelical Hermeneutics, pages 308-9. Kregel, Grand Rapids, MI, 2002.

[Tig96] Jeffrey. H. Tigay. Deuteronomy, page 137. JPS Torah Commentary. Jewish Publication Society, Philadelphia, PA, 1996.

[Wal96] Daniel B. Wallace. Greek Grammar Beyond the Basics. Zondervan Publishing, Grand Rapids, MI, 1996.

[Walog] John H. Walton. The Lost World of Genesis One: Ancient Cosmology and the Origins Debate. IVP Academic, Downers Grove, IL, 2009.

[Wal12] John H. Walton. Job, pages 23-24. NIV Application Commentary. Zondervan, Grand Rapids, MI, 2012.

[Wal13] John Walton. No historical Adam: Response from the archetypal view. In Ardel B. Caneday and Matthew Barrett, editors, Four Views on The Historical Adam, pages 108-13. Zondervan, Grand Rapids, MI, 2013.

[Wat27] Leroy Waterman. Cosmogonic affinities in Genesis 1:2. The American Journal of Semitic Languages and Literatures, 43(3):181, 1927.

[Wil15] Lindsay Wilson. Job, pages 135-37. Two Horizons Old Testament Commentary. Eerdmans Publishing, Grand Rapids, MI, 2015.

[WOgo] Bruce K. Waltke and M. O'Connor. An Introduction to Biblical Hebrew Syntax. Eisenbrauns, Winona Lake, IN, 1990. 